Article

\title{
Eco-Friendly Materials Obtained by Fly Ash Sulphuric Activation for Cadmium Ions Removal
}

\author{
Gabriela Buema ${ }^{1}$, Nicoleta Lupu $\left.{ }^{1} \mathbb{(}\right)$, Horia Chiriac ${ }^{1}$, Tiberiu Roman ${ }^{1,2} \mathbb{D}^{-}$, Marieta Porcescu ${ }^{1}$, \\ Gabriela Ciobanu ${ }^{3}$, Daniela Vasilica Burghila ${ }^{4}$ and Maria Harja ${ }^{3, *}$ \\ 1 National Institute of Research and Development for Technical Physics, 47 Mangeron Boulevard, \\ 700050 Iasi, Romania; gbuema@phys-iasi.ro (G.B.); nicole@phys-iasi.ro (N.L.); hchiriac@phys-iasi.ro (H.C.); \\ troman@phys-iasi.ro (T.R.); porcescu@phys-tuiasi.ro (M.P.) \\ 2 Integrated Center of Environmental Science Studies in the North Eastern Region-CERNESIM, “Alexandru \\ Ioan Cuza" University of Iasi, Carol I nr. 11 Blvd., 700506 Iasi, Romania \\ 3 Faculty of Chemical Engineering and Environmental Protection, "Gheorghe Asachi” Technical University of \\ Iasi, 73 Prof.dr.doc. Dimitrie Mangeron Street, 700050 Iasi, Romania; gciobanu@tuiasi.ro \\ 4 Faculty of Land Reclamation and Environmental Engineering, University of Agronomical Sciences and \\ Veterinary Medicine of Bucharest, 59 Mărăști Blvd., 011464 Bucharest, Romania; dburghila@gmail.com \\ * Correspondence: mharja@tuiasi.ro; Tel.: +40-74-790-9645
}

Received: 20 July 2020; Accepted: 11 August 2020; Published: 13 August 2020

\begin{abstract}
Wastes are the sustainable sources of raw materials for the synthesis of new adsorbent materials. This study has as objectives the advanced capitalization of fly ash, by sulphuric acid activation methods, and testing of synthesized materials for heavy metals removal. Based on the previous studies, the synthesis parameters were $1 / 3 \mathrm{~s} / \mathrm{L}$ ratio, $80^{\circ} \mathrm{C}$ temperature and $10 \%$ diluted sulphuric acid, which permitted the synthesis of an eco-friendly adsorbent. The prepared adsorbent was characterized through SEM, EDX, FTIR, XRD and BET methods. Adsorption studies were carried out for the removal of $\mathrm{Cd}^{2+}$ ions, recognized as ions dangerous for the environment. The effects of adsorbent dose, contact time and metal ion concentrations were studied. The data were tested in terms of Langmuir and Freundlich isotherm and it was found that the Langmuir isotherm fitted the adsorption with a maximum adsorption capacity of $28.09 \mathrm{mg} / \mathrm{g}$. Kinetic data were evaluated with the pseudo-first-order model, the pseudo-second-order model and the intraparticle diffusion model. The kinetics of cadmium adsorption into eco-friendly material was described with the pseudo-second-order model, which indicated the chemisorption mechanism.
\end{abstract}

Keywords: acidic fly ash modification; adsorption; cadmium ions; isotherms; kinetic models

\section{Introduction}

The presence of different pollutants in water that are characterized by their non-biodegradable nature can affect the environment and humans' health [1-3]. Due to pollutants, heavy metals occur in a significant number of places; this type of pollutant represents one of the biggest environmental problems [4,5]. Consequently, a sustainable solution must be found in order to solve this problem. Out of all possible removal methods, adsorption is one of the most applied techniques for treating contaminated waters due to some advantageous criteria, such as high performance, low cost, easy operation, wide $\mathrm{pH}$ range, etc. [6,7]. Out of all the available adsorbents, activated carbon and zeolites can be used; for low cost adsorbents, however, fly ash, modified ash, agricultural wastes, etc., are considered [7-9].

As a result of coal combustion, fly ash is found in large quantities and it has been reported that this fact causes serious environmental problems [10,11]; therefore, it must be addressed [12,13]. Fly ash is rich in aluminosilicate and includes polymeric minerals and inorganic oxide material $[14,15]$. 
The use of ash as an adsorbent for the retention of heavy metals is a widely studied field [16-19]. To increase the adsorption capacity, activation of the material surface by using acid or base chemical treatment is recommended. Studies have shown that the modification of ash can be done in different ways [16,20-23]. By applying one of these methods, various zeolitic structures are obtained: Analcime (A), Chabazite (Cha), Cancrinite (Can), NaP1, Na-Y, Sodalite (S), Fau (Faujasite) [11,24].

The new materials obtained by modification have been continuously investigated in recent decades regarding the treatment of wastewater [8,17,20,25-28]. The literature presents different adsorbents based on modified fly ash for cadmium adsorption [25]. Unfortunately, there is no data available regarding the adsorption of $\mathrm{Cd}^{2+}$ ions into acid activated fly ash. Therefore, a detailed study regarding the utilization of this material by evaluating the adsorption process is necessary.

The research was performed in May-June 2020 at The National Institute of Research and Development for Technical Physics, Romania. It is the continuation of the experiments where the adsorption capacity of modified fly ash with sodium hydroxide for the removal of $\mathrm{Cd}^{2+}$ ions was tested [25]. In this study, for the first time, fly ash treated with $\mathrm{H}_{2} \mathrm{SO}_{4}$ was used for adsorption of $\mathrm{Cd}^{2+}$ ions from aqueous solutions. The equilibrium data were modeled using Langmuir and Freundlich isotherm models; the kinetics data were designed based on the pseudo-first order, pseudo-second order and intraparticle diffusion models. A characterization of synthesized adsorbent is also included in this paper.

\section{Materials and Methods}

\subsection{Materials}

The fly ash was supplied by CET II Holboca, a thermo-electric power plant from Iasi, North Romania. The fly ash was a priori characterized and the properties have been published in previous papers [29]. Of the properties studied in this research, the important ones are: Particle size 0.01-100 $\mu \mathrm{m}$; chemical composition: $\mathrm{SiO}_{2}-58.62 \% ; \mathrm{Al}_{2} \mathrm{O}_{3}-16.98 \% ; \mathrm{Fe}_{2} \mathrm{O}_{3}-8.78 \% ; \mathrm{CaO}-8.41 \%$; $\mathrm{MgO}-1.29 \%$; and other components also up to $0.5 \%$ [29].

The chemical reagents were analytical grade and were used as received from Sigma Aldrich.

$\mathrm{Cd}^{2+}$ was the heavy metal studied in this research. It is recognized as one of the most toxic heavy metals that enter into water due to various activities, so its removal is required [25].

An aqueous solution of cadmium nitrate was prepared by dissolving a quantity of $\mathrm{Cd}\left(\mathrm{NO}_{3}\right)_{2}$ $4 \mathrm{H}_{2} \mathrm{O}$ into $1 \mathrm{~L}$ of water in order to obtain an initial solution of $1000 \mathrm{mg} / \mathrm{L}$. The working solutions of 50-320 mg/L were prepared by diluting the stock solution of $\mathrm{Cd}\left(\mathrm{NO}_{3}\right)_{2} 4 \mathrm{H}_{2} \mathrm{O}(1000 \mathrm{mg} / \mathrm{L})$.

For synthesized material, SEM and EDAX analyses were carried out using Vega Tescan LMH II (Brno-Kohoutovice, Czech Republic) and Bruker EDAX with XFlash detector (Brno, Czech Republic), FTIR analysis was realized with the Bruker Vertex 60 device (Ettlingen, Germany), specific surface area was calculated with the BET method using low-temperature nitrogen adsorption/desorption data obtained via Quantachrome instruments, the Nova 2200e model (Graz, Austria), and X-ray diffraction (XRD) patterns were recorded using an Advance D8-Bruker X-ray diffractometer with $\mathrm{Cu}-\mathrm{K} \alpha$ radiation (Malvern, United Kingdom).

\subsection{Adsorbent Synthesis}

The fly ash, without any processing, was mixed with the sulfuric acid solution. The acid quantity was determined by the stoichiometry of reactions between the iron, aluminum and calcium oxides, assuring a $5-10 \%$ excess. A quantity of $200 \mathrm{~g}$ of fly ash and $500 \mathrm{~mL}$ of $10 \%$ sulfuric acid solution was added to the reactor [30], the mixture was stirred mechanically at $200 \mathrm{rot} / \mathrm{min}, 80^{\circ} \mathrm{C}$, and the curing time was $2 \mathrm{~h}$. After that time, the $\mathrm{FA} / \mathrm{H}_{2} \mathrm{SO}_{4}$ was cooled at ambient temperature for $18 \mathrm{~h}$ to ensure the crystallization of the new products and was filtered and dried at $70{ }^{\circ} \mathrm{C}$ until the weight was constant. The prepared solid was stored in a drying vessel and used as $\mathrm{FA} / \mathrm{H}_{2} \mathrm{SO}_{4}$. 


\subsection{Experimental Procedure}

The adsorption experiments for the evaluation of the material adsorption capacities, including the study of the influence of adsorbent dose, initial concentration, and contact time, were performed as follows:

$\mathrm{FA} / \mathrm{H}_{2} \mathrm{SO}_{4}$ dose influence: Different quantities of adsorbent $(8-20 \mathrm{~g} / \mathrm{L})$ were added to $25 \mathrm{~mL}$ of $\mathrm{Cd}^{2+}$ concentration of $70 \mathrm{mg} / \mathrm{L}$ at $\mathrm{pH} 5.0 \pm 0.1$, room temperature and contact time $24 \mathrm{~h}$ (for reaching equilibrium), with intermittent stirring;

Initial concentration influence: A dose of $8 \mathrm{~g} / \mathrm{L}$ of adsorbent was added to $25 \mathrm{~mL}$ of $\mathrm{Cd}^{2+}$ concentration $(50-320 \mathrm{mg} / \mathrm{L}), \mathrm{pH} 5.0 \pm 0.1$, room temperature, and contact time $24 \mathrm{~h}$, with intermittent stirring;

Contact time influence: A dose of $8 \mathrm{~g} / \mathrm{L}$ of adsorbent was added to $25 \mathrm{~mL}$ of $\mathrm{Cd}^{2+}$ concentration of $70 \mathrm{mg} / \mathrm{L}, \mathrm{pH} 5.0 \pm 0.1$, temperature $24.6^{\circ} \mathrm{C}$, contact time $5-120 \mathrm{~min}$, with intermittent stirring.

The $\mathrm{Cd}^{2+}$ concentration in the supernatant solution was measured using the UV-visible spectrophotometry method at $576 \mathrm{~nm}$ (Perkin Elmer Lambda 35 UV/VIS spectrophotometer-Llantrisant, United Kingdom). All the results were carried out in triplicate.

The amount of equilibrium adsorption capacity was evaluated according to the equation [31]:

$$
q=\frac{\left(C_{0}-C_{e}\right) V}{m}
$$

where $C_{0}$ and $C_{e}$ are the initial and equilibrium $\mathrm{Cd}^{2+}$ concentrations $(\mathrm{mg} / \mathrm{L}), q$ is the amount of $\mathrm{Cd}^{2+}$ adsorbed onto $\mathrm{FA} / \mathrm{H}_{2} \mathrm{SO}_{4}(\mathrm{mg} / \mathrm{g}), V$ is the volume of solution $(L)$ and $m$ is the quantity of $\mathrm{FA} / \mathrm{H}_{2} \mathrm{SO}_{4}(\mathrm{~g})$.

The adsorption capacity at different time intervals (5-120 $\mathrm{min}$ ) was calculated with Equation (2):

$$
q_{t}=\frac{\left(C_{0}-C_{t}\right) V}{m}
$$

where $C_{t}$ is $\mathrm{Cd}^{2+}$ concentrations at different time intervals $(\mathrm{mg} / \mathrm{L}), q_{t}$ is the amount of $\mathrm{Cd}^{2+}$ adsorbed onto $\mathrm{FA} / \mathrm{H}_{2} \mathrm{SO}_{4}$ at time intervals $=5-120 \mathrm{~min}, V$ is the volume of solution $(\mathrm{L})$, and $m$ is the quantity of $\mathrm{FA} / \mathrm{H}_{2} \mathrm{SO}_{4}$ (g).

\section{Results}

\subsection{Characterization of Adsorbent}

The characterization of the $\mathrm{FA} / \mathrm{H}_{2} \mathrm{SO}_{4}$ adsorbent was performed by SEM, EDX, FTIR, XRD and BET points of view. Moreover, SEM, EDX, FTIR and XRD analyses for $\mathrm{FA} / \mathrm{H}_{2} \mathrm{SO}_{4}$ after $\mathrm{Cd}^{2+}$ adsorption, noted as $\mathrm{FA} / \mathrm{H}_{2} \mathrm{SO}_{4}+\mathrm{Cd}^{2+}$, were included.

\subsubsection{SEM Analysis}

Figure 1 shows SEM analyses for $\mathrm{FA} / \mathrm{H}_{2} \mathrm{SO}_{4}$ and for $\mathrm{FA} / \mathrm{H}_{2} \mathrm{SO}_{4}+\mathrm{Cd}^{2+}$. SEM analysis (Figure 1a) indicates that the surface of $\mathrm{FA} / \mathrm{H}_{2} \mathrm{SO}_{4}$ material contains spherical shapes with different sizes and smooth surfaces, similar to unmodified fly ash $[4,24,32]$. 


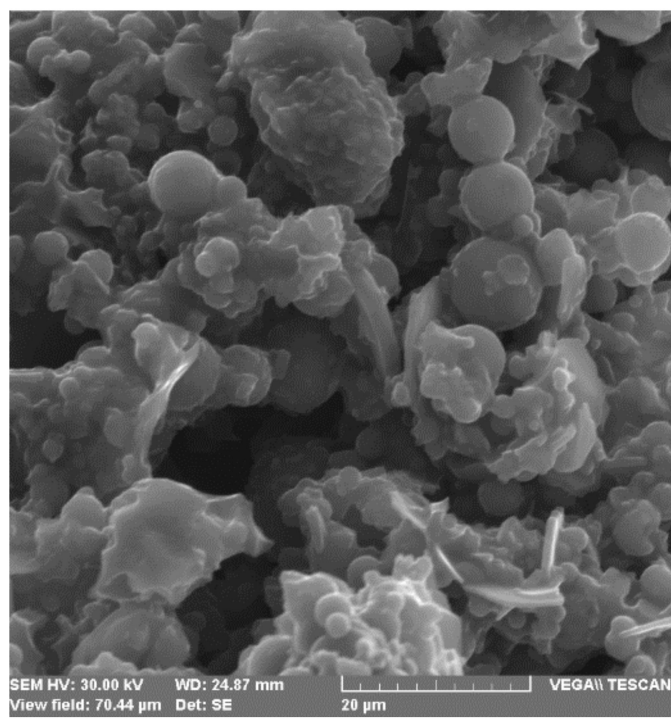

(a)

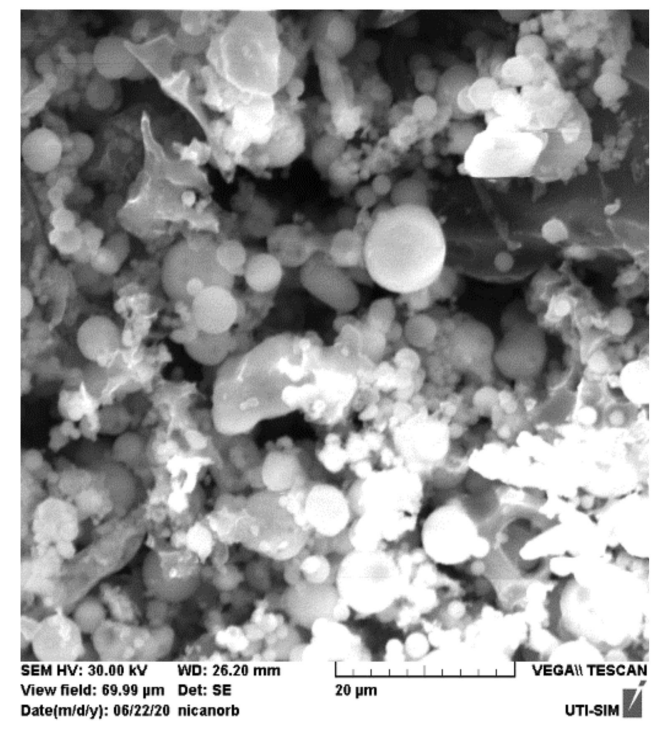

(b)

Figure 1. SEM images for $\mathrm{FA} / \mathrm{H}_{2} \mathrm{SO}_{4}(\mathbf{a})$ and $\mathrm{FA} / \mathrm{H}_{2} \mathrm{SO}_{4}+\mathrm{Cd}^{2+}(\mathbf{b})$, at a resolution of $20 \mu \mathrm{m}$.

The white patches that can be seen in Figure $1 \mathrm{~b}$ can be explained by the presence of $\mathrm{Cd}^{2+}$ on the surface of $\mathrm{FA} / \mathrm{H}_{2} \mathrm{SO}_{4}$ material. Moreover, this fact could be observed in the case of $\mathrm{U}(\mathrm{VI})$ uptake onto the adsorbent based on ash [16].

It can be observed that the widths of FA were decomposed into small particles. This is a result of sulphuric acid activation, which can destroy the whole structure of FA by the reaction of acid with the alkali and oxide compounds $\left(\mathrm{CaO}, \mathrm{MgO}, \mathrm{Al}_{2} \mathrm{O}_{3}, \mathrm{Fe}_{2} \mathrm{O}_{3}\right.$, etc.). In light of Figure $1 \mathrm{~b}$, it can be observed that $\mathrm{FA} / \mathrm{H}_{2} \mathrm{SO}_{4}$ has a relative quantity of the smaller particle sizes.

\subsubsection{EDX Analysis}

Furthermore, EDX analysis for $\mathrm{FA} / \mathrm{H}_{2} \mathrm{SO}_{4}$ was recorded in order to establish the elemental composition. The results are presented in Figure 2a and Table 1.

Table 1. Elemental composition of $\mathrm{FA} / \mathrm{H}_{2} \mathrm{SO}_{4}$.

\begin{tabular}{cc}
\hline Element & Mass, \% \\
\hline $\mathrm{O}$ & 59.82826 \\
$\mathrm{Si}$ & 20.07406 \\
$\mathrm{Al}$ & 8.967165 \\
$\mathrm{Ca}$ & 2.286939 \\
$\mathrm{Fe}$ & 1.500967 \\
$\mathrm{~K}$ & 1.039111 \\
$\mathrm{Mg}$ & 0.872161 \\
$\mathrm{Na}$ & 0.638949 \\
$\mathrm{Ti}$ & 0.344842 \\
$\mathrm{~S}$ & 4.447546 \\
\hline
\end{tabular}

EDX analysis of $\mathrm{FA} / \mathrm{H}_{2} \mathrm{SO}_{4}$ reveals the peaks for $\mathrm{O}, \mathrm{Si}$ and $\mathrm{Al}$ elements and smaller peaks for elements such as $\mathrm{Ca}, \mathrm{Fe}, \mathrm{K}, \mathrm{Mg}$, $\mathrm{Na}$ and Ti. 

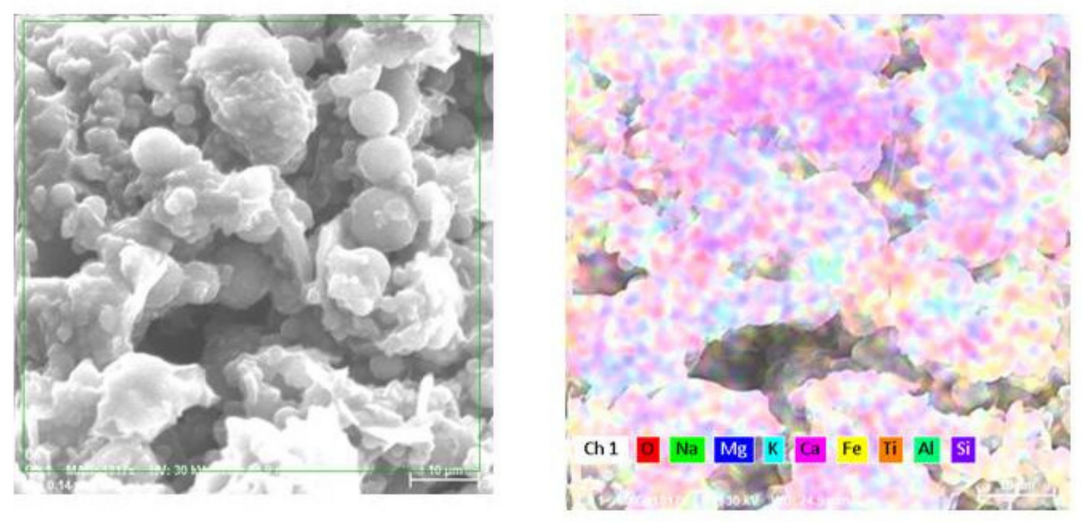

a

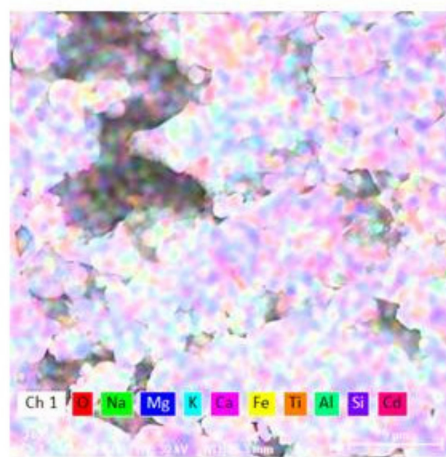

b

Figure 2. Elemental analysis by EDX for $\mathrm{FA} / \mathrm{H}_{2} \mathrm{SO}_{4}(\mathbf{a}) ; \mathrm{FA} / \mathrm{H}_{2} \mathrm{SO}_{4}+\mathrm{Cd}^{2+}(\mathbf{b})$.

Moreover, the EDX spectrum of the FA/H2SO4+Cd ${ }^{2+}$ sample is presented in Figure $2 \mathrm{~b}$ and Table 2. The adsorption of $\mathrm{Cd}^{2+}$ was confirmed by the peak of $\mathrm{Cd}$ in the EDX spectrum.

Table 2. Elemental composition of $\mathrm{FA} / \mathrm{H}_{2} \mathrm{SO}_{4}+\mathrm{Cd}^{2+}$.

\begin{tabular}{cc}
\hline Element & Mass, $\%$ \\
\hline $\mathrm{O}$ & 53.8552 \\
$\mathrm{Si}$ & 26.6605 \\
$\mathrm{Al}$ & 10.7206 \\
$\mathrm{Ca}$ & 0.7185 \\
$\mathrm{Fe}$ & 1.8664 \\
$\mathrm{~K}$ & 1.7000 \\
$\mathrm{Mg}$ & 0.5995 \\
$\mathrm{Na}$ & 0.5135 \\
$\mathrm{Ti}$ & 0.3448 \\
$\mathrm{Cd}$ & 3.0207 \\
\hline
\end{tabular}

\subsubsection{FTIR Analysis}

FTIR analysis was employed to establish the functional groups that could provide information concerning the structure of the adsorbent. In Figure 3 the FTIR spectra for $\mathrm{FA} / \mathrm{H}_{2} \mathrm{SO}_{4}$ and $\mathrm{FA} / \mathrm{H}_{2} \mathrm{SO}_{4}+\mathrm{Cd}^{2+}$ can be seen. 


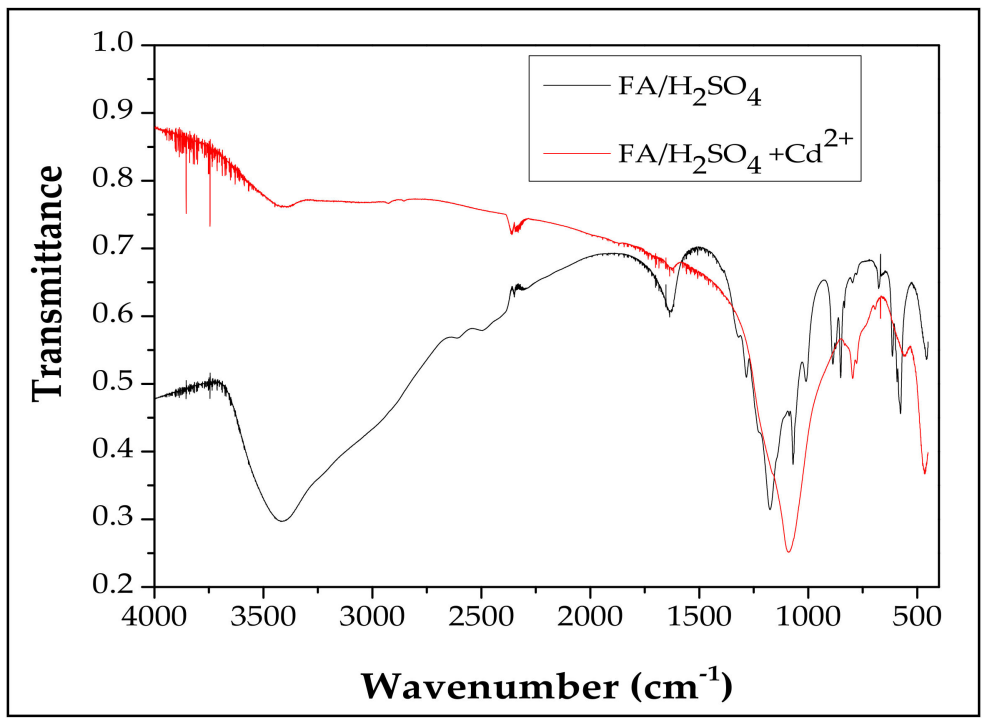

Figure 3. FTIR spectra of $\mathrm{FA} / \mathrm{H}_{2} \mathrm{SO}_{4}$ and $\mathrm{FA} / \mathrm{H}_{2} \mathrm{SO}_{4}+\mathrm{Cd}^{2+}$.

Regarding the FA/ $\mathrm{H}_{2} \mathrm{SO}_{4}$ sample, the new bands found at $1629 \mathrm{~cm}^{-1}, 888 \mathrm{~cm}^{-1}$ and $848 \mathrm{~cm}^{-1}$ in comparison with unmodified fly ash [29] can be explained by the presence of S-O on the unmodified fly ash surface. Based on the results, it can be concluded that the synthesis was successfully done.

On the other hand, after $\mathrm{Cd}^{2+}$ adsorption there was a shift in the bands between $1700 \mathrm{~cm}^{-1}$ and $400 \mathrm{~cm}^{-1}$, which proves the adsorption process of $\mathrm{Cd}^{2+}$ on the $\mathrm{FA} / \mathrm{H}_{2} \mathrm{SO}_{4}$ sample [33,34].

\subsubsection{XRD Analysis}

Figure 4 represents the comparison of XRD patterns between $\mathrm{FA} / \mathrm{H}_{2} \mathrm{SO}_{4}$ and $\mathrm{FA} / \mathrm{H}_{2} \mathrm{SO}_{4}+\mathrm{Cd}^{2+}$.

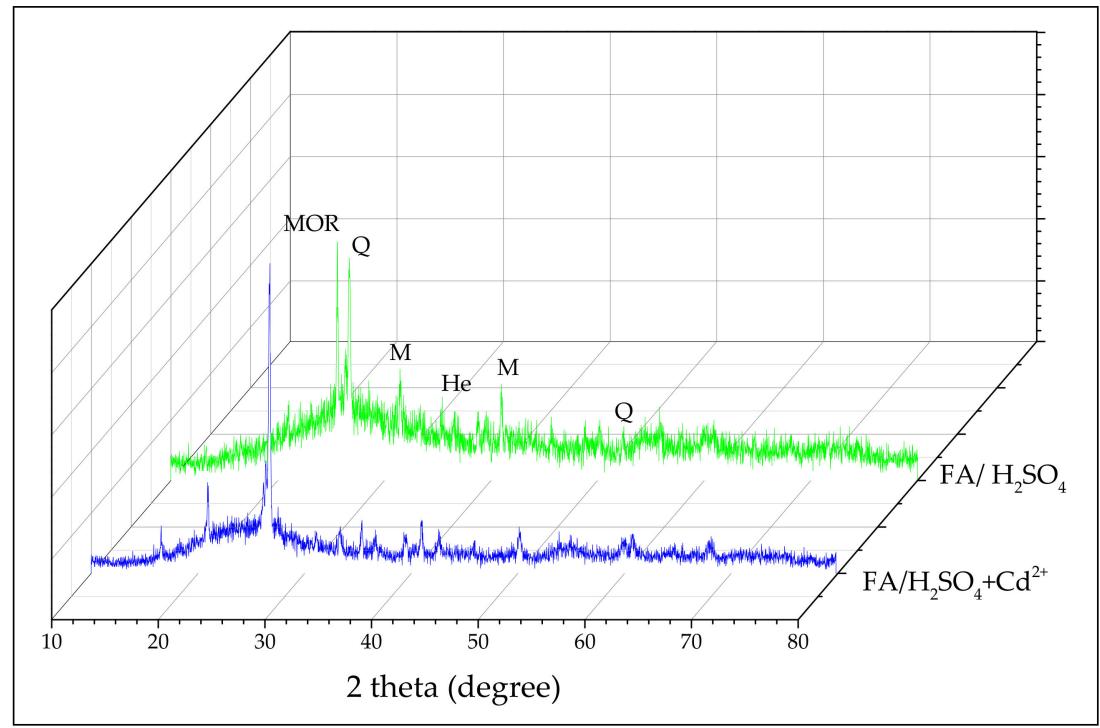

Figure 4. X-ray diffraction patterns of $\mathrm{FA} / \mathrm{H}_{2} \mathrm{SO}_{4}$ and $\mathrm{FA} / \mathrm{H}_{2} \mathrm{SO}_{4}+\mathrm{Cd}^{2+}$.

One significant observation is that the results of $\mathrm{XRD}$ analysis revealed that quartz $(\mathrm{Q})$ presents the highest intensity-mullite $(\mathrm{M})$ and hematite $(\mathrm{He})$; the mainly crystalline phases of the unmodified fly ash [26] can also be identified in $\mathrm{FA} / \mathrm{H}_{2} \mathrm{SO}_{4}$. Additionally, $\mathrm{FA} / \mathrm{H}_{2} \mathrm{SO}_{4}$ shows a prominent peak at 2 theta $=25.63^{\circ}$ that can be attributed to modernite $(\mathrm{MOR})\left[\mathrm{Na}_{8}\left(\mathrm{H}_{2} \mathrm{O}\right)_{24}\right]\left[\mathrm{Si}_{40} \mathrm{Al}_{8} \mathrm{O}_{96}\right][35,36]$. In the 
case of $\mathrm{FA} / \mathrm{H}_{2} \mathrm{SO}_{4}+\mathrm{Cd}^{2+}$ the peaks can be observed in minor intensity. On the other hand X-ray diffraction patterns indicate that a large part of the amorphous silica is present in the tested samples.

\subsubsection{BET Analysis}

The $\mathrm{N}_{2}$ adsorption-desorption isotherm is shown in Figure 5.

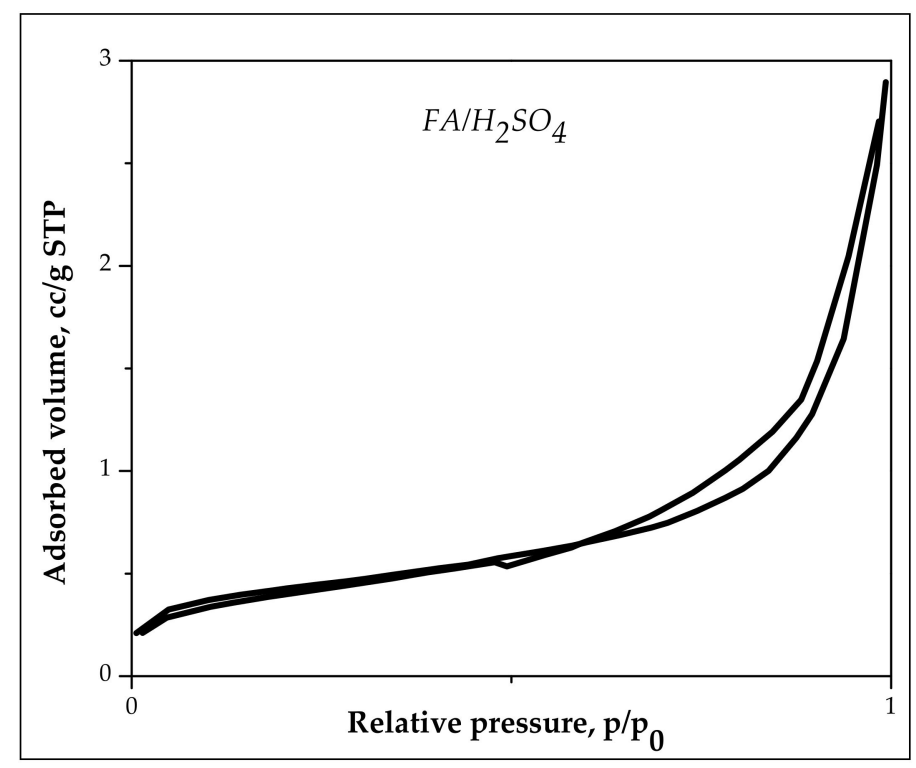

Figure 5. Nitrogen adsorption isotherm at $77 \mathrm{~K}$ on $\mathrm{FA} / \mathrm{H}_{2} \mathrm{SO}_{4}$.

The BET results shows that the specific surface area of $\mathrm{FA} / \mathrm{H}_{2} \mathrm{SO}_{4}$ is 1.53 times higher compared with FA [8]; the specific area for $\mathrm{FA} / \mathrm{H}_{2} \mathrm{SO}_{4}$ is $10.71 \mathrm{~m}^{2} / \mathrm{g}$. In addition, the modification of chemical components (alkali substance, metallic oxides) by acid activation increases the pore volume and decreases the average pore diameter. The total pore volume was $0.068 \mathrm{~cm}^{3} / \mathrm{g}$ for FA $/ \mathrm{H}_{2} \mathrm{SO}_{4}$, a comparative increase compared to $0.042 \mathrm{~cm}^{3} / \mathrm{g}$ for raw fly ash. The diameters of the pores were smaller than $18.7 \mathrm{~nm}$.

All physical and chemical changes of FA are the essential features of the sulphuric acid-based activation of $\mathrm{FA} / \mathrm{H}_{2} \mathrm{SO}_{4}$. To determine whether a material can be proposed as an adsorbent for the retention of heavy metals and also for establishing the optimal adsorption experimental conditions, at least two parameters should be evaluated.

\subsection{Effect of $\mathrm{FA} / \mathrm{H}_{2} \mathrm{SO}_{4}$ Dose in $\mathrm{Cd}^{2+}$ Adsorption}

Studies have proved that the recommended $\mathrm{pH}$ for the removal of $\mathrm{Cd}^{2+}$ must be below 6.5, because at a higher $\mathrm{pH}$ value the precipitation of $\mathrm{Cd}(\mathrm{OH})_{2}$ in solution can occur [25,37].

Adsorbent dose should be a parameter studied in the adsorption technique of different pollutants from wastewaters since it has an important role in terms of process economy $[38,39]$. Determining the optimal dose of the adsorbent was carried out by increasing the $\mathrm{FA} / \mathrm{H}_{2} \mathrm{SO}_{4}$ dose from $0.2 \mathrm{~g} / 25 \mathrm{~mL}$ to $0.5 \mathrm{~g} / 25 \mathrm{~mL}$ at an initial concentration of $70 \mathrm{mg} / \mathrm{L}$. The effect of the adsorbent dose through adsorption capacity is presented in Figure 6.

Furthermore, the effect of adsorbent dose on the adsorption capacity indicated that, as the adsorbent dose increases from 8 to $20 \mathrm{~g} / \mathrm{L}$, the adsorption capacity decreases from $5.37 \mathrm{mg} / \mathrm{g}$ to $1.98 \mathrm{mg} / \mathrm{g}$. It was found that these results are consistent with the published literature [34]. The explanation could be that at higher adsorbent dose, aggregation of particles takes place. Therefore, for all further experiments adsorbent dose was fixed at $8 \mathrm{~g} / \mathrm{L}$ solution. 


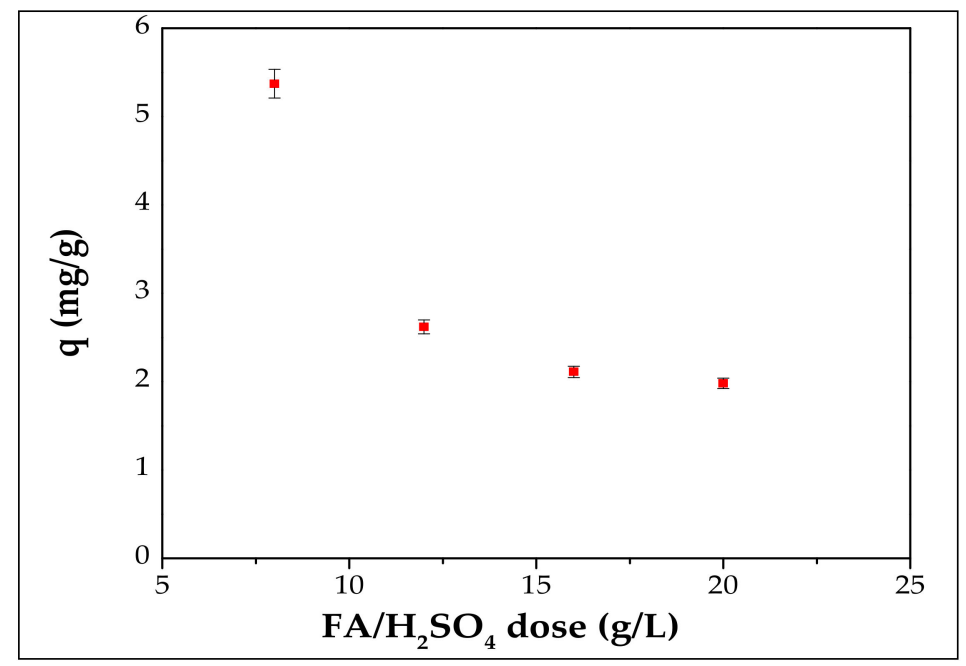

Figure 6. Effect of $\mathrm{FA} / \mathrm{H}_{2} \mathrm{SO}_{4}$ dose in $\mathrm{Cd}^{2+}$ adsorption.

\subsection{Effect of Initial Concentration and Adsorption Isotherm}

For the optimization of this parameter, different concentrations of $\mathrm{Cd}^{2+}(50-320 \mathrm{mg} / \mathrm{L})$ were applied and the results are presented in Figure 7.

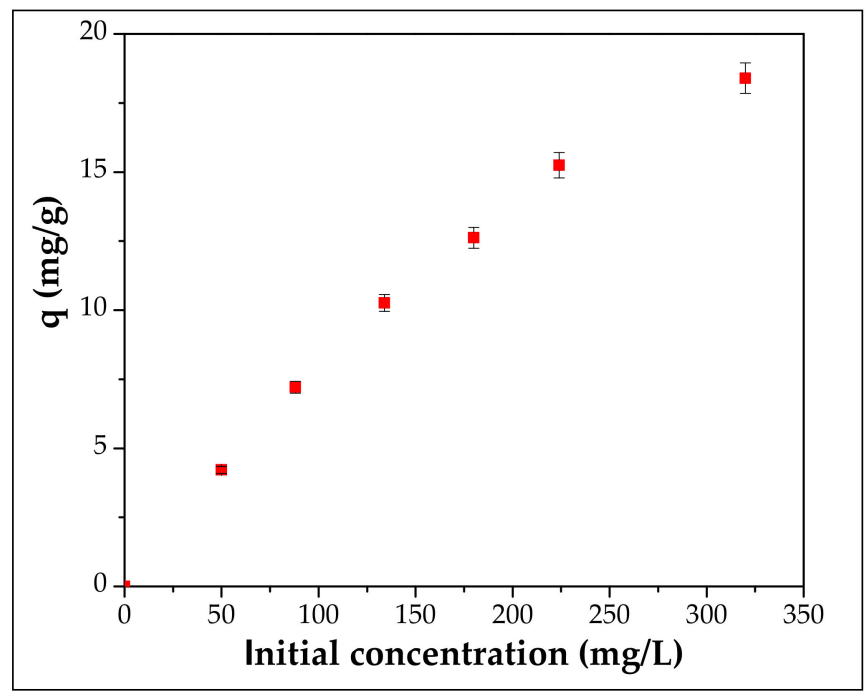

Figure 7. Effect of initial concentration on the adsorption of $\mathrm{Cd}^{2+}$ onto adsorbent.

It is obvious that the initial concentration has an impact on the adsorption capacity; thus, at low concentrations small adsorption capacity values are obtained, and as the concentration increases, the adsorption capacity also increases. For example, at an initial $\mathrm{Cd}^{2+}$ concentration of $50 \mathrm{mg} / \mathrm{L}$ the adsorption capacity is equal with $4.22 \mathrm{mg} / \mathrm{g}$, while at $320 \mathrm{mg} / \mathrm{L}$ initial $\mathrm{Cd}^{2+}$ concentration, the adsorption capacity increased by approximately $78 \%$. Experimental results at $\mathrm{Cd}^{2+}$ concentration range of 50-320 mg/L were explained based on Langmuir and Freundlich adsorption isotherm model points of view and the corresponding parameters were obtained accordingly.

A plot of $C_{e} / q$ vs. $C_{e}$ (Langmuir) and $\operatorname{lnq}_{e}$ vs. $\ln C_{e}$ (Freundlich) enables the determining of the coefficients (Figures 8 and 9 and Table 3). 


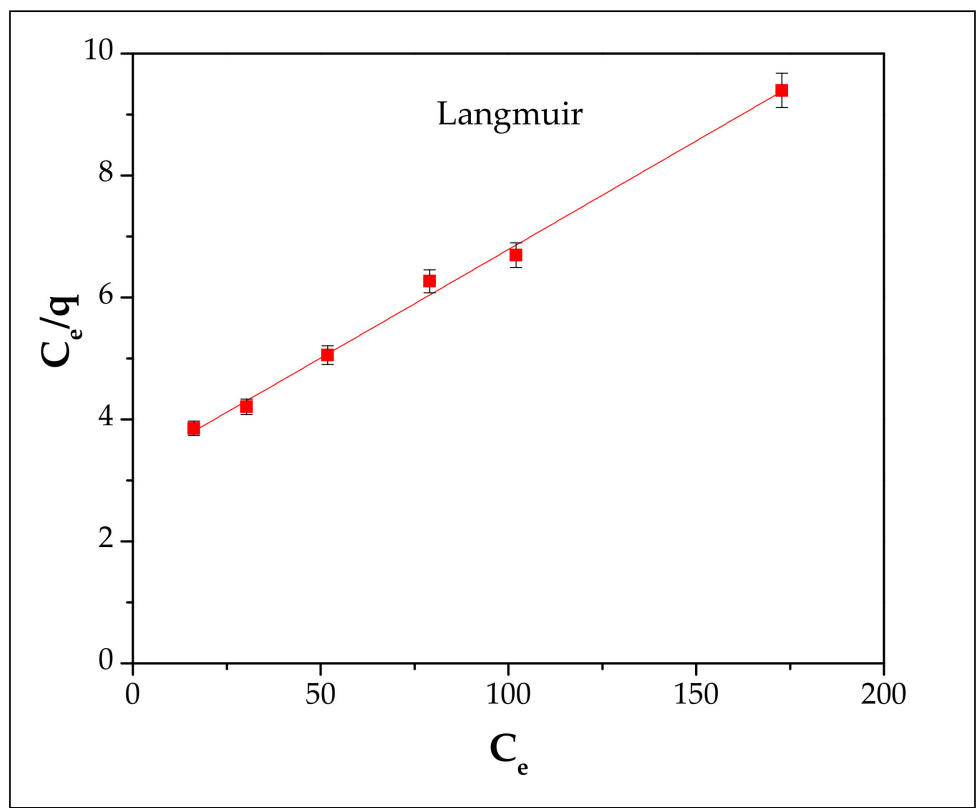

Figure 8. Langmuir isotherm plot of $\mathrm{Cd}^{2+}$ adsorption on $\mathrm{FA} / \mathrm{H}_{2} \mathrm{SO}_{4}$.

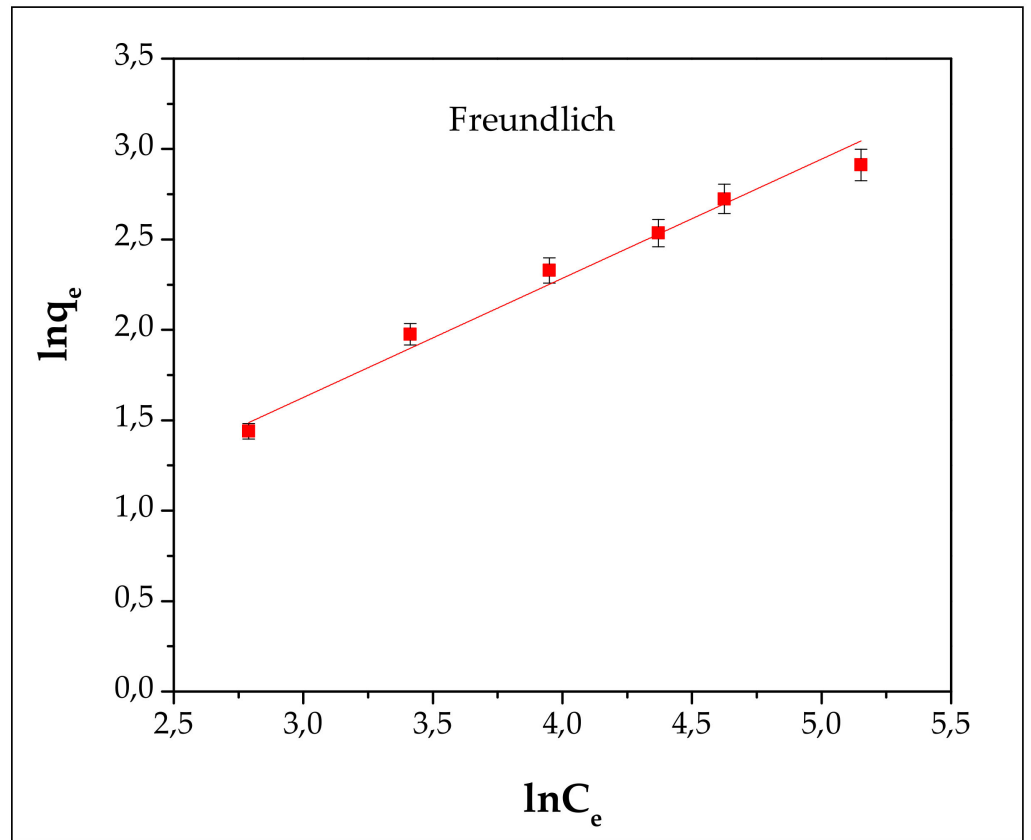

Figure 9. Freundlich isotherm plot of $\mathrm{Cd}^{2+}$ adsorption on $\mathrm{FA} / \mathrm{H}_{2} \mathrm{SO}_{4}$.

Table 3. Adsorption isotherm parameters of $\mathrm{Cd}^{2+}$ onto $\mathrm{FA} / \mathrm{H}_{2} \mathrm{SO}_{4}$.

\begin{tabular}{|c|c|c|c|c|c|}
\hline \multicolumn{3}{|c|}{$\begin{array}{l}\text { Langmuir Model } \\
\frac{C_{e}}{q_{e}}=\frac{1}{K_{L} q_{\max }}+\frac{C_{e}}{q_{\max }}\end{array}$} & \multicolumn{3}{|c|}{$\begin{array}{c}\text { Freundlich Model } \\
\log q_{e}=\left(\frac{1}{n}\right) \log q_{e}+\log K_{F}\end{array}$} \\
\hline$q_{\max }$ & $K_{L}$ & $R^{2}$ & $K_{\mathrm{F}}$ & $1 / n$ & $R^{2}$ \\
\hline 28.09 & 0.0110 & 0.9956 & 6.23 & 0.2101 & 0.9806 \\
\hline
\end{tabular}

$q_{\max }$ is the maximum adsorption capacity $(\mathrm{mg} / \mathrm{g}) ; K_{L}$ is Langmuir constant $(\mathrm{L} / \mathrm{g}) ; K_{F}$ is the Freundlich constant; $1 / \mathrm{n}$ is the heterogeneity factor; $q_{e}$ is the amount of heavy metal adsorbed at equilibrium $(\mathrm{mg} / \mathrm{g}) ; C_{e}$ is the concentration at equilibrium $(\mathrm{mg} / \mathrm{L})$. 
According to the $\mathrm{R}^{2}$ value of the Langmuir (0.9956) and Freundlich (0.9806) isotherms, it can be highlighted that the Langmuir model is suitable for describing the adsorption process of $\mathrm{Cd}^{2+}$ onto $\mathrm{FA} / \mathrm{H}_{2} \mathrm{SO}_{4}$.

\subsection{Effect of Contact Time and Kinetic Models}

It is very common in the literature that the adsorption takes place in two stages: (a) An initial stage that includes the fast adsorption in the first minutes from the beginning of the adsorption process and (b) a final stage that include the slow adsorption.

The adsorption capacity was investigated as a function of contact time at $70 \mathrm{mg} / \mathrm{L}$ initial $\mathrm{Cd}^{2+}$ concentration, pH 5.0 and an adsorbent dose of $8 \mathrm{~g} / \mathrm{L}$. The kinetic of adsorption of $\mathrm{Cd}^{2+}$ was carried out by withdrawing and analyzing the samples until the adsorption capacities became closer. The results are presented in Figure 10.

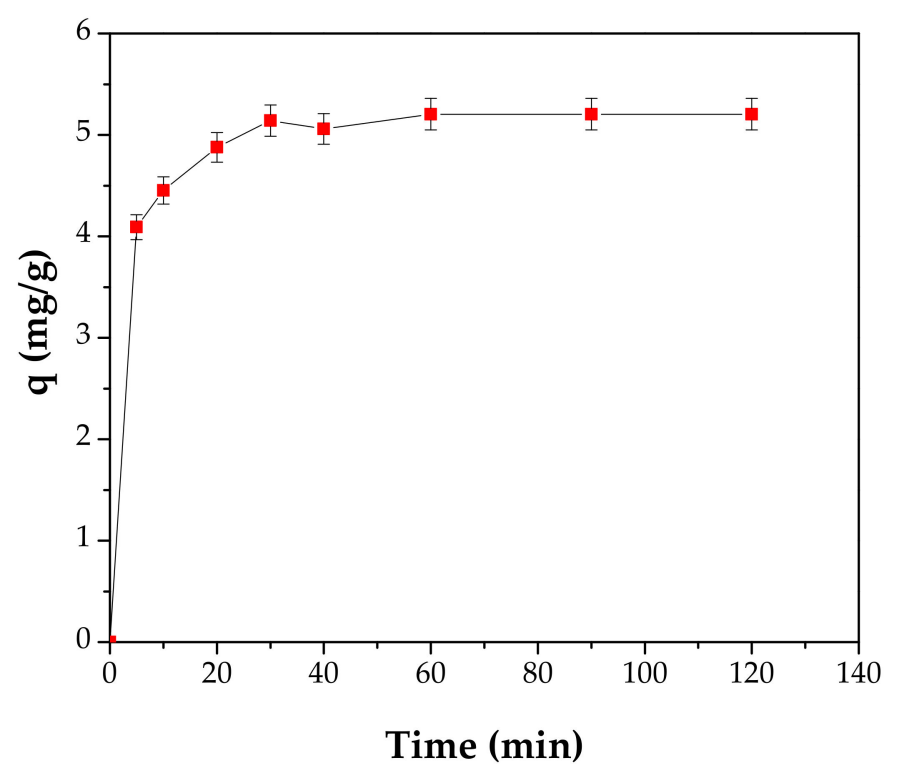

Figure 10. Effect of contact time on $\mathrm{Cd}^{2+}$ adsorption, $\mathrm{C}_{0} 70 \mathrm{mg} / \mathrm{L}, \mathrm{pH} 5$ and $8 \mathrm{~g} / \mathrm{L}$ adsorbent dose.

From Figure 10 it can be noted that the adsorption capacity increased quickly from 4.09 to $5.2 \mathrm{mg} / \mathrm{g}$ as the contact time increased from 5 to $60 \mathrm{~min}$. By increasing the contact time to $120 \mathrm{~min}$, a plateau is obtained. This fact could be explained as follows: The increase of the contact time determines the filling of the pores and thus the rate becomes slower.

It might be concluded that a contact time of 60 min could be considered sufficient for $60 \%$ adsorption under the experimental conditions.

Three kinetic models, the pseudo-first-order model, pseudo-second-order model and intraparticle diffusion model have been developed in order to describe the adsorption kinetic process of $\mathrm{Cd}^{2+}$ onto material, see Figures 11-13 and Table 4. A detailed presentation for each model can be consulted in the literature [24,40,41].

The linearized form of the pseudo-first-order model is presented as follows:

$$
\log \left(q_{e}-q_{t}\right)=\log q_{e}-\frac{\left(k_{1} t\right)}{2.303}
$$

The linearized form of the pseudo-second-order model is:

$$
\frac{t}{q_{t}}=\frac{1}{k_{2} q_{e}^{2}}+\frac{t}{q_{e}}
$$


The intraparticle diffusion model is based on Equation (5):

$$
q_{t}=k_{i} t^{0.5}
$$

where $q_{e}$ is the amount of $\mathrm{Cd}^{2+}$ adsorbed at equilibrium $(\mathrm{mg} / \mathrm{g}), q_{t}$ is the amount of $\mathrm{Cd}^{2+}$ adsorbed at time $\mathrm{t}(\mathrm{mg} / \mathrm{g}), k_{1}$ and $k_{2}$ are the reaction rate constants of the pseudo-first order $(1 / \mathrm{min})$ and pseudo-second order ( $\mathrm{g} / \mathrm{mg} \cdot \mathrm{min}) ; k_{i}$ is the intraparticle diffusion rate constant.

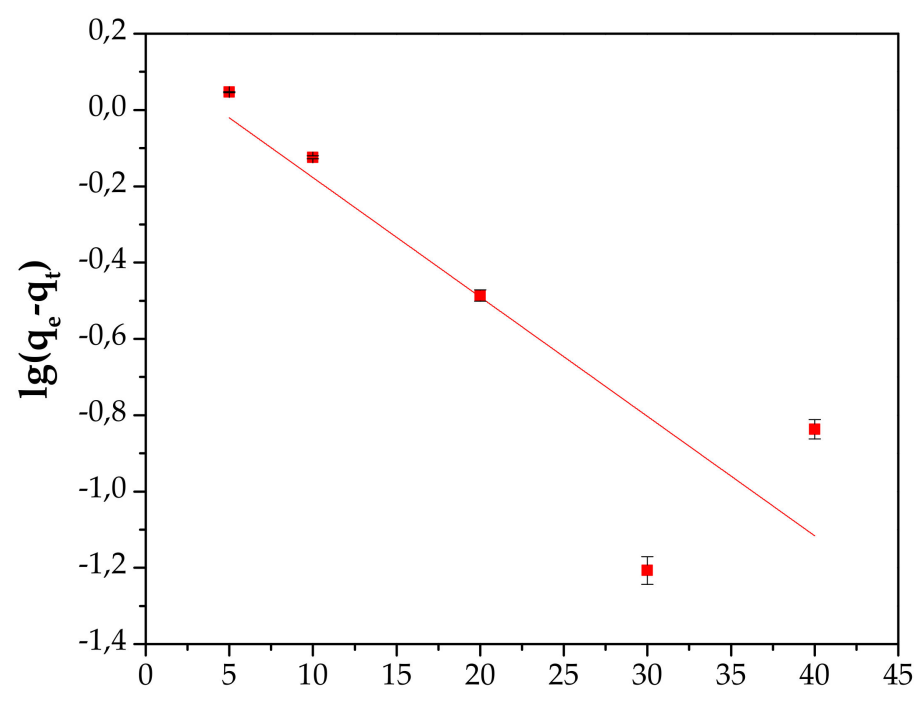

Time (min)

Figure 11. Pseudo-first-order kinetics.

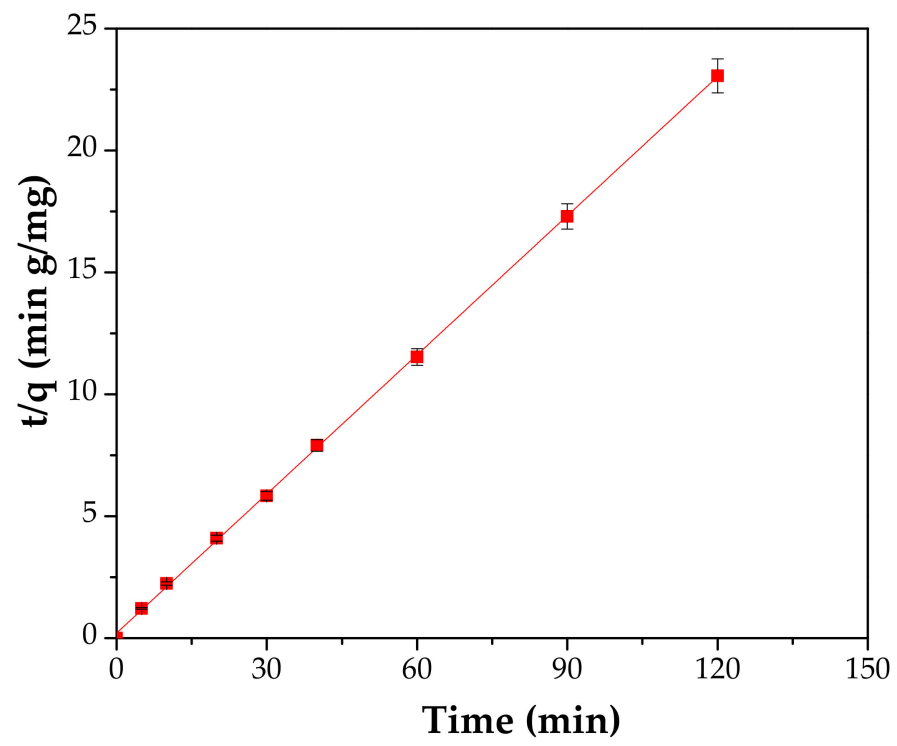

Figure 12. Pseudo-second-order kinetics.

For this study, the pseudo-second-order model describes the adsorption of $\mathrm{Cd}^{2+}$ onto the adsorbent, with a coefficient regression, $\mathrm{R}^{2}$, of 0.9999 . The experimental $q_{e}$ value of $5.2 \mathrm{mg} / \mathrm{g}$ is in agreement with the $q_{e}$ value of $5.28 \mathrm{mg} / \mathrm{g}$ calculated from the pseudo-second-model and the $k_{2}$ constant has a value of $0.1308 \mathrm{~g} / \mathrm{mg} \cdot \mathrm{min}$. 


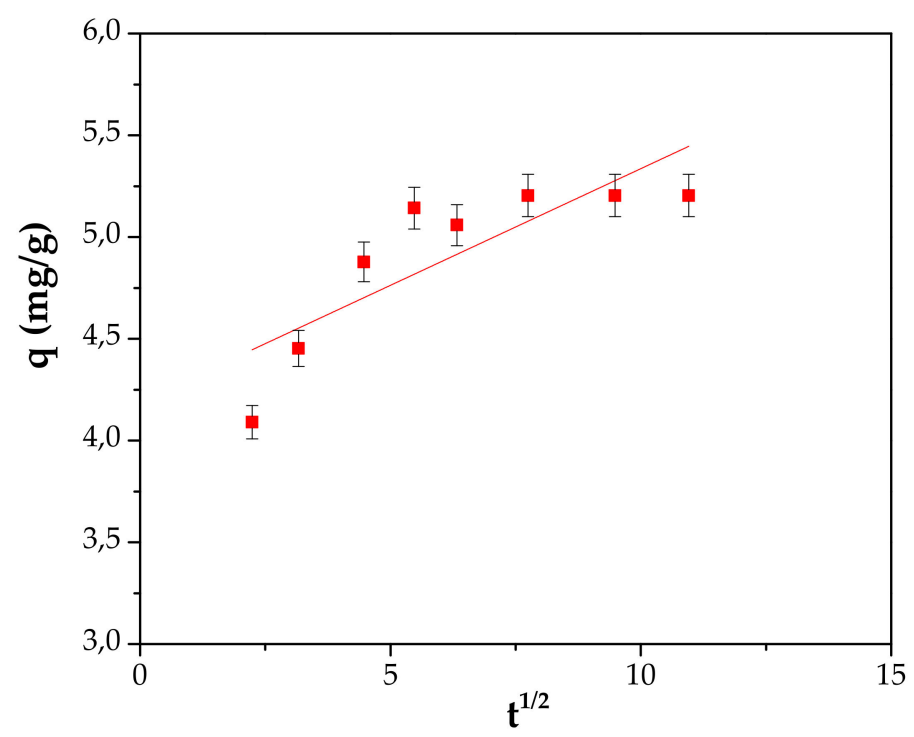

Figure 13. Intraparticle difussion model.

Table 4. Kinetic parameters of $\mathrm{Cd}^{2+}$ adsorption onto the $\mathrm{FA} / \mathrm{H}_{2} \mathrm{SO}_{4}$ sample.

\begin{tabular}{ccc}
\hline Kinetic model & Parameters & Values \\
\hline Pseudo-first order & $k_{1}, 1 / \mathrm{min}$ & 0.071 \\
& $R^{2}$ & 0.763 \\
\hline Pseudo-second order & $\mathrm{q}_{\mathrm{e} \mathrm{cal}}, \mathrm{mg} / \mathrm{g}$ & 5.28 \\
& $k_{2}, \mathrm{~g} / \mathrm{mg} \cdot \mathrm{min}$ & 0.1308 \\
& $\mathrm{R}^{2}$ & $\mathbf{0 . 9 9 9 9}$ \\
\hline Intraparticle diffusion & $k_{i}, \mathrm{mg} / \mathrm{g} \cdot \mathrm{min}^{0.5}$ & 0.114 \\
& $\mathrm{R}^{2}$ & 0.693 \\
\hline
\end{tabular}

The results obtained in this study show that this adsorbent can successfully treat the waters contaminated with $\mathrm{Cd}^{2+}$ ions (Table 5).

Table 5. Comparison of maximum $\mathrm{Cd}^{2+}$ adsorption capacities $\left(\mathrm{q}_{\max }\right)$ of different adsorbents reported in literature.

\begin{tabular}{ccc}
\hline Adsorbent & $\mathbf{q}_{\max }(\mathbf{m g} / \mathbf{g})$ & References \\
\hline Iranian natural zeolite & 4.01 & {$[42]$} \\
Modified fly ash & 43.12 & {$[25]$} \\
Bottom ash & 13.70 & {$[37]$} \\
Coated Industrial Waste Fly Ash & 6.39 & {$[43]$} \\
NaOH modified ash & 31.79 & {$[28]$} \\
Swine manure biochar & 46.5 & {$[44]$} \\
USA clinoptilolite-K & 24.5 & {$[45]$} \\
RSA clinoptilolite-K & 20.73 & {$[45]$} \\
Palm Oil Fuel Ash & 10.56 & {$[14]$} \\
$\mathrm{Fe}_{3} \mathrm{O}_{4} @ P D A$ & 21.58 & {$[47]$} \\
Ceramsite/C-A-S-H/TCPS & 14.27 & {$[34]$} \\
$\mathrm{Fe}_{3} \mathrm{O}_{4} @ \mathrm{Z}$ & 19.9 & This study \\
$\boldsymbol{F A}_{\mathbf{H}} \mathbf{H}_{\mathbf{2}} \mathbf{S O}_{\mathbf{4}}$ & $\mathbf{2 8 . 0 9}$ &
\end{tabular}

\section{Conclusions}

This study confirmed that the $\mathrm{FA} / \mathrm{H}_{2} \mathrm{SO}_{4}$ material could remove $\mathrm{Cd}^{2+}$ ions from an aqueous solution with the following main observations: 
- The adsorbent dose had an effect on the adsorption process: A higher dose led to a decrease in adsorption capacity.

- Moreover, it was found that the adsorption process is dependent on the initial concentration.

- The adsorption equilibrium was reached after $60 \mathrm{~min}$ of contact time.

- The data fitted in the Langmuir model with a maximum adsorption capacity of $28.09 \mathrm{mg} / \mathrm{g}$. The adsorption process could be explained through a pseudo-second-order kinetic model. This suggests the dominance of chemisorption and monolayer adsorption.

- The adsorption study demonstrated that the material is an effective adsorbent for the removal of cadmium ions from aqueous solutions.

The use of this type of adsorbent could solve the associated environmental and health effects.

Author Contributions: Conceptualization, M.H. and G.B.; methodology, N.L. and G.C.; formal analysis, H.C.; investigation, G.B., T.R., M.P. and D.V.B.; writing-original draft preparation, G.B.; writing-review and editing, D.V.B., M.H.; visualization, N.L.; supervision, G.C. and M.H. All authors have read and agreed to the published version of the manuscript.

Funding: This research was funded by the UEFISCDI Agency trough Project PN-III-P1-1.2-PCCDI-2017-0152 (Contract No. 75PCCDI/2018).

Conflicts of Interest: The authors declare no conflict of interest.

\section{References}

1. Baby, R.; Hussein, M.Z. Ecofriendly approach for treatment of heavy-metal-contaminated water using activated carbon of kernel shell of oil Palm. Materials 2020, 13, 2627. [CrossRef]

2. Huang, X.; Zhao, H.; Zhang, G.; Li, J.; Yang, Y.; Ji, P. Potential of removing Cd (II) and Pb (II) from contaminated water using a newly modified fly ash. Chemosphere 2020, 242, 125148. [CrossRef]

3. Roman, T.; Asavei, R.L.; Karkalos, N.E.; Roman, C.; Virlan, C.; Cimpoesu, N.; Istrate, B.; Zaharia, M.; Markopoulos, A.P.; Kordatos, K.; et al. Synthesis and adsorption properties of nanocrystalline ferrites for kinetic modeling development. Int. J. Appl. Ceram. Technol. 2019, 16, 693-705. [CrossRef]

4. Favier, L.; Harja, M. $\mathrm{TiO}_{2} / \mathrm{fly}$ ash nanocomposite for photodegradation of persistent organic pollutant. In Handbook of Nanomaterials and Nanocomposites for Energy and Environmental Applications; Kharissova, O., Martínez, L., Kharisov, B., Eds.; Springer: Basel, Switzerland, 2020. [CrossRef]

5. Harja, M.; Ciobanu, G. Ecofriendly nano-adsorbents for pollutant removal from wastewaters. In Handbook of Nanomaterials and Nanocomposites for Energy and Environmental Applications; Kharissova, O., Martínez, L., Kharisov, B., Eds.; Springer: Basel, Switzerland, 2020.

6. Kokkinos, E.; Chousein, C.; Simeonidis, K.; Coles, S.; Zouboulis, A.; Mitrakas, M. Improvement of manganese feroxyhyte's surface charge with exchangeable $\mathrm{Ca}$ ions to maximize $\mathrm{Cd}$ and $\mathrm{Pb}$ uptake from water. Materials 2020, 13, 1762. [CrossRef] [PubMed]

7. Zhang, Y.; Wang, Q.; Li, R.; Lou, Z.; Li, Y. A novel phenolic foam-derived magnetic carbon foam treated as adsorbent for rhodamine B: Characterization and adsorption kinetics. Crystals 2020, 10, 159. [CrossRef]

8. Noli, F.; Buema, G.; Misaelides, P.; Harja, M. New materials synthesized from ash under moderate conditions for removal of toxic and radioactive metals. J. Radioanal. Nucl. Chem. 2015, 303, 2303-2311. [CrossRef]

9. Wang, Y.; Han, P.; Lu, Y.; Xiao, L.; Du, Y.; Liu, X.; Ye, S. Removal of arsenic and heavy metals from arsenic-containing acid wastewater with iron salt and lime. Environ. Eng. Manag. J. 2019, 18, $2655-2662$. [CrossRef]

10. Liu, S.; Yang, C.; Liu, W.; Yi, L.; Qin, W. A novel approach to preparing ultra-lightweight ceramsite with a large amount of fly ash. Front. Environ. Sci. Eng. 2020, 14, 62-73. [CrossRef]

11. Harja, M.; Cimpeanu, S.M.; Dirja, M.; Bucur, D. Synthesis of zeolites from fly ash and their use as soil amendment. In Zeolites-Useful Minerals; IntechOpen: London, UK, 2016.

12. Pivák, A.; Pavlíková, M.; Záleská, M.; Lojka, M.; Jankovský, O.; Pavlík, Z. Magnesium oxychloride cement composites with silica filler and coal fly ash admixture. Materials 2020, 13, 2537. [CrossRef]

13. Risdanareni, P.; Villagran, Y.; Schollbach, K.; Wang, J.; De Belie, N. Properties of alkali activated lightweight aggregate generated from sidoarjo volcanic mud (lusi), fly ash, and municipal solid waste incineration bottom ash. Materials 2020, 13, 2528. [CrossRef] 
14. Lei, T.; Li, S.J.; Jiang, F.; Ren, Z.X.; Wang, L.L.; Yang, X.J.; Tang, L.H.; Wang, S.X. Adsorption of cadmium ions from an aqueous solution on a highly stable dopamine-modified magnetic nano adsorbent. Nanoscale Res. Lett. 2019, 14, 352. [CrossRef] [PubMed]

15. Supelano, G.I.; Cuaspud, J.G.; Moreno-Aldana, L.C.; Ortiz, C.; Trujillo, C.A.; Palacio, C.A. Synthesis of magnetic zeolites from recycled fly ash for adsorption of methylene blue. Fuel 2020, 263, 116800. [CrossRef]

16. Buema, G.; Noli, F.; Misaelides, P.; Sutiman, D.M.; Cretescu, I.; Harja, M. Uranium removal from aqueous solutions by raw and modified thermal power plant ash. J. Radioanal. Nucl. Chem. 2014, 299, 381-386. [CrossRef]

17. Noli, F.; Kapnisti, M.; Buema, G.; Harja, M. Retention of barium and europium radionuclides from aqueous solutions on ash-based sorbents by application of radiochemical techniques. Appl. Radiat. Isot. 2016, 116, 102-109. [CrossRef] [PubMed]

18. Li, X.; Ye, J.; Liu, Z.; Qiu, Y.; Li, L.; Mao, S.; Wang, X.; Zhang, Q. Microwave digestion and alkali fusion assisted hydrothermal synthesis of zeolite from coal fly ash for enhanced adsorption of Cd(II) in aqueous solution. J. Cent. South Univ. 2018, 25, 9-20. [CrossRef]

19. Zhang, Y.; Zhou, L.; Chen, L.; Guo, Y.; Guo, F.; Wu, J.; Dai, B. Synthesis of zeolite Na-P1 from coal fly ash produced by gasification and its application as adsorbent for removal of $\mathrm{Cr}(\mathrm{VI})$ from water. Front. Chem. Sci. Eng. 2020. [CrossRef]

20. Noli, F.; Buema, G.; Misaelides, P.; Harja, M. Retention of cesium from aqueous solutions using synthetic zeolites produced from power plant ash. J. Radioanal. Nucl. Chem. 2016, 309, 589-596. [CrossRef]

21. Mor, S.; Chhavi, M.K.; Sushil, K.K.; Ravindra, K. Assessment of hydrothermally modified fly ash for the treatment of methylene blue dye in the textile industry wastewater. Environ. Dev. Sustain. 2018, 20, 625-639. [CrossRef]

22. Styszko, K.; Szczurowski, J.; Czuma, N.; Makowska, D.; Kistler, M.; Uruski, L. Adsorptive removal of pharmaceuticals and personal care products from aqueous solutions by chemically treated fly ash. Int. J. Environ. Sci. Technol. 2018, 15, 493-506. [CrossRef]

23. Ileri, B.; SanliyukselYucel, D. Metal removal from acid mine lake using ultrasound-assisted modified fly ash at different frequencies. Environ. Monit. Assess. 2020, 192, 185. [CrossRef]

24. Harja, M.; Buema, G.; Sutiman, D.M.; Munteanu, C.; Bucur, D. Low cost adsorbents obtained from ash for copper removal. Korean J. Chem. Eng. 2012, 29, 1735-1744. [CrossRef]

25. Harja, M.; Buema, G.; Bulgariu, L.; Bulgariu, D.; Sutiman, D.M.; Ciobanu, G. Removal of cadmium(II) from aqueous solution by adsorption onto modified algae and ash. Korean J. Chem. Eng. 2015, 32, 1804-1811. [CrossRef]

26. Harja, M.; Buema, G.; Sutiman, D.M.; Cretescu, I. Removal of heavy metal ions from aqueous solutions using low-cost sorbents obtained from ash. Chem. Pap. 2013, 67, 497-508. [CrossRef]

27. Nguyen, T.C.; Loganathan, P.; Nguyen, T.V.; Kandasamy, J.; Naidu, R.; Vigneswaran, S. Adsorptive removal of five heavy metals from water using blast furnace slag and fly ash. Environ. Sci. Pollut. Res. 2018, 25, 20430-20438. [CrossRef] [PubMed]

28. Zhao, H.; Huang, X.; Zhang, G.; Li, J.; He, Z.; Ji, P.; Zhao, J. Possibility of removing cadmium pollution from the environment using a newly synthesized material coal fly ash. Environ. Sci. Pollut. Res. 2020, 27, 4997-5008. [CrossRef]

29. Harja, M.; Bărbuţă, M.; Rusu, L.; Apostolescu, N. Utilization of coal fly ash from power plants I. Ash characterization. Environ. Eng. Manag. J. 2008, 7, 289-294. [CrossRef]

30. Forminte (Litu), L.; Ciobanu, G.; Buema, G.; Lupu, N.; Chiriac, H.; Gomez de Castro, C.; Harja, M. New materials synthesized by sulfuric acid attack over power plant fly ash. Rev. Chim 2020, 71, 48-58. [CrossRef]

31. Buema, G.; Lupu, N.; Chiriac, H.; Ciobanu, G.; Kotova, O.; Harja, M. Modeling of solid-fluid non-catalytic processes for nickel ion removal. Rev. Chim. 2020, 71, 4-15. [CrossRef]

32. Harja, M.; Barbuta, M.; Gavrilescu, M. Study of morphology for geopolymer materials obtained from fly ash. Environ. Eng. Manag. J. 2009, 8, 1021-1027. [CrossRef]

33. Ma, L.; Wei, Q.; Chen, Y.; Song, Q.; Sun, C.; Wang, Z.; Wu, G. Removal of cadmium from aqueous solutions using industrial coal fly ash-nZVI. R. Soc. Open Sci. 2018, 5, 171051. [CrossRef] 
34. Jorfi, S.; Shooshtarian, M.R.; Pourfadakari, S. Decontamination of cadmium from aqueous solutions using zeolite decorated by $\mathrm{Fe}_{3} \mathrm{O}_{4}$ nanoparticles: Adsorption modeling and thermodynamic studies. Int. J. Environ. Sci. Technol. 2020, 17, 273-286. [CrossRef]

35. Treacy, M.M.; Higgins, J.B. Collection of Simulated XRD Powder Patterns for Zeolites, 5th ed.; Elsevier: Amsterdam, The Netherlands, 2007.

36. Wang, N.; Hao, L.; Chen, J.; Zhao, Q.; Xu, H. Adsorptive removal of organics from aqueous phase by acid-activated coal fly ash: Preparation, adsorption, and Fenton regenerative valorization of "spent" adsorbent. Environ. Sci. Pollut. Res. 2018, 25, 12481-12490. [CrossRef] [PubMed]

37. Sukpreabprom, H.; Arqueropanyo, O.; Naksata, W.; Sooksamiti, P.; Janhom, S. Single and binary adsorption of Cd (II) and Zn (II) ions from aqueous solutions onto bottom ash. Korean J. Chem. Eng. 2015, 32, 896-902. [CrossRef]

38. Gorzin, F.; Abadi, M.B.R. Adsorption of $\mathrm{Cr}(\mathrm{VI})$ from aqueous solution by adsorbent prepared from paper mill sludge: Kinetics and thermodynamics studies. Adsorp. Sci. Technol. 2018, 36, 149-169. [CrossRef]

39. Yusuff, A.S.; Popoola, L.T.; Babatunde, E.O. Adsorption of cadmium ion from aqueous solutions by copper-based metal organic framework: Equilibrium modeling and kinetic studies. Appl. Water Sci. 2019, 9, 106. [CrossRef]

40. Zhang, Y.; Lou, Z.; Wang, C.; Wang, W.; Cai, J. Synthesis of porous Fe/C bio-char adsorbent for rhodamine B from waste wood: Characterization, kinetics and thermodynamics. Processes 2019, 7, 150. [CrossRef]

41. Wang, Z.; Li, J.; Zhang, G.; Zhi, Y.; Yang, D.; Lai, X.; Ren, T. Characterization of acid-aged biochar and its ammonium adsorption in an aqueous solution. Materials 2020, 13, 2270. [CrossRef]

42. Merrikhpour, H.; Jalali, M. Comparative and competitive adsorption of cadmium, copper, nickel, and lead ions by Iranian natural zeolite. Clean Technol. Environ. Policy 2013, 15, 303-316. [CrossRef]

43. Olabemiwo, F.A.; Tawabini, B.S.; Patel, F.; Oyehan, T.A.; Mazen Khaled, M.; Laoui, T. Cadmium removal from contaminated water using polyelectrolyte-coated industrial waste fly ash. Bioinorg. Chem. Appl. 2017, 7298351. [CrossRef]

44. Deng, Y.; Huang, S.; Laird, D.A.; Wang, X.; Dong, C. Quantitative mechanisms of cadmium adsorption on rice straw- and swine manure-derived biochars. Environ. Sci. Pollut. Res. 2018, 25, 32418-32432. [CrossRef]

45. Gorimbo, J.; Taenzana, B.; Muleja, A.A.; Kuvarega, A.T.; Jewell, L.L. Adsorption of cadmium, nickel and lead ions: Equilibrium, kinetic and selectivity studies on modified clinoptilolites from the USA and RSA. Environ. Sci. Pollut. Res. 2018, 25, 30962-30978. [CrossRef] [PubMed]

46. Yusof, M.S.M.; Othman, M.H.D.; Mustafa, A.; Rahman, M.A.; Jaafar, J.; Ismail, A.F. Feasibility study of cadmium adsorption by palm oil fuel ash (POFA)-based low-cost hollow fibre zeolitic membrane. Environ. Sci. Pollut. Res. 2018, 25, 21644-21655. [CrossRef] [PubMed]

47. Zhao, D.; Liu, P.; Wang, F.; Hu, C.; Hu, S. Versatile surface modification of ceramsite via honeycomb calcium-aluminum-silicate-hydrate and its functionalization by 3-thiocyanatopropyltriethoxysilane for enhanced cadmium (II) removal. J. Wuhan Univ. Technol. Mater. Sci. Ed. 2020, 35, 71-80. [CrossRef]

(C) 2020 by the authors. Licensee MDPI, Basel, Switzerland. This article is an open access article distributed under the terms and conditions of the Creative Commons Attribution (CC BY) license (http://creativecommons.org/licenses/by/4.0/). 